\title{
Present conservation status of red wood ants in north-western Belgium: Worse than previously, but not a lost cause
}

\author{
Wouter DEKONINCK ${ }^{1,2}$, Frederik HENDRICKX $^{1,2}$, PAtrick GROOTAERT $^{1}$ and JeAN-Pierre MAELFAIT ${ }^{2,3 \uparrow}$ \\ ${ }^{1}$ Royal Belgian Institute of Natural Sciences, Entomology Department, Vautierstraat 29, B-1000 Brussels, Belgium; \\ e-mail: wdekoninck@natuurwetenschappen.be \\ ${ }^{2}$ Terrestrial Ecology Unit, Ghent University, K.L. Ledeganckstraat 35, B-9000 Ghent, Belgium \\ ${ }^{3}$ Research Institute for Nature and Forest, Kliniekstraat 25, B-1070 Brussels, Belgium
}

Key words. Red wood ants, conservation, disturbance mitigation, Serviformica, social organisation, habitat preference

\begin{abstract}
The number of colonies of red wood ants (Formica rufa group) in the north western part of Belgium has declined by more than half over the past 20 years. In the study area of $20 \times 50 \mathrm{~km}$ there are currently only 36 colonies of two species of red wood ants (Formica rufa and $F$. polyctena). Both species form both monodomous and polydomous colonies. Monodomous $F$. rufa colonies occur in large areas of open woodland dominated by Pinus sylvestris. The other three types of red wood ant (F. rufa polydomous, $F$. polyctena mono- and polydomous) occur in clearings or along the margins of small areas of deciduous or mixed woodland. The extinction of red wood ants cannot be attributed to a loss of their main habitat. Their decline in abundance, however, appears to be due to the deterioration in their habitat caused by several factors. Shading by overgrowing shrubs and the closure of the tree canopy, nearby intensive agriculture, urbanisation and use of the forest for recreation are the more important factors threatening and ultimately leading to the extinction of colonies. At poor quality sites there are no or very few nests of Serviformica ants, which initially serve as host ants and are necessary for recolonization by red wood ants. Thus, it is unlikely that these sites will be recolonized. To conserve red wood ants and maintain populations there is an urgent need to undertake certain measures, especially in areas outside nature reserves. For this there is a need to create clearings in the woodland, reduce shading due to overgrowing shrubs and closure of the tree canopy, and mitigate the effects of intensive agriculture, urbanisation and recreation. It is important that the effects of these measures should be monitored.
\end{abstract}

\section{INTRODUCTION}

Species of the Formica rufa group are key-stone species in European conifer and mixed conifer-hardwood forests. These polyphagous predators are thought to control the abundance of their prey (Adlung, 1966; Skinner, 1980). Their nests harbour many symbiont species (e.g. 30 species of beetles in the Netherlands, Mabelis, 2007 and 73 myrmecophilous species in Scandinavia, Päivinen et al., 2002), and the ants disperse the seeds of myrmecochorous forest plants (e.g. Viola sp., Gorb \& Gorb, 1995) and are a reliable source of food for higher trophic levels (e.g. woodpeckers, ant lions and amphibians, De Bruyn et al., 1972). The below ground activities of ants and other species living in their nests (e.g. earthworms) are important for the development of forest soils (Laakso \& Setälä, 1997; Lenoir et al., 2003).

Eight species of red wood ants are on the IUCN Red List of Threatened species (IUCN, 2008), 6 of which belong to the F. rufa group in Europe (Seifert, 2007). Red wood ants are vulnerable to direct disturbance caused by commercial collection of pupae for bird food, destruction and fragmentation of suitable habitat (Gyllenstrand \& Seppä, 2003; Mäki-Petäys et al., 2005), deforestation (Sorvari \& Hakkarainen, 2005) and general lack of appropriate habitat management (Domisch et al., 2005).

Because of their wide occurrence in Europe these ants are the focus of extensive research on their social struc- ture (Rosengren et al., 1993), geographical distribution (Collingwood, 1979), density, population dynamics and behaviour (Petal, 1994; Czechowski \& Vepsäläinen, 1999), community structure (Pisarski \& Vepsäläinen, 1989; Savolainen et al., 1989; Vepsäläinen et al., 2000) and biodiversity (Laakso \& Setälä, 1997; Hawes et al., 2002). In this context it is clear that red wood ants are good umbrella species for nature conservation planning as their nests are easily monitored (Mabelis, 2002; MakiPetäys et al., 2005).

Among Belgian ants, Formica species are the most popular. As is the case for most ant species, there are no long-term studies on their distribution in Belgium. Recent distribution maps of red wood ants in Flanders show that Formica rufa and $F$. polyctena are chiefly found in the northern and eastern part (Campine region and north of the cities Ghent and Bruges), where there are sandy thermophilic soils (Dekoninck et al., 2003; Loones et al., 2008). In the western part they are mainly present in a strongly declining habitat that consists of large forest complexes with patches of thermophilic nutrient poor grasslands and heathland.

There are no detailed studies on the conservation status and habitat preference of red wood ants in Flanders (Loones et al., 2008). However, such information is indispensable for sustainable conservation of red wood ants in Flanders as scattered observations by amateur naturalists 
in the $70 \mathrm{~s}-80 \mathrm{~s}$ suggest that there has been a dramatic decline in the abundance of Formica ants.

The decline in red wood ants is associated with habitat fragmentation and deterioration, and features of their lifehistory strategies. Queens of the species in the Formica rufa group are incapable of independently founding a colony. Hence, to establish a new colony, a queen must be accepted into a nest of a species belonging to the subgenus Serviformica (generally $F$. fusca), because she is unable to raise her own brood (Seifert, 2007). As the success rate of being adopted by these host ants is very low (Gösswald, 1952), colonization of new areas by means of flying queens is assumed to be risky (Rosengren \& Pamilo, 1983). Nevertheless, it may be the optimal strategy when a woodland habitat is highly fragmented as in the Netherlands, eastern-Germany and the south of Poland (Seifert, 1991; Mabelis \& Korczyńska, 2001; Mabelis, 1994, 2002) as monodomous and monogynous colonies occur mainly in such landscapes. Another way of founding a colony is cursorial dispersal by budding as reported for $F$. polyctena, (Mabelis, 1979). In this case, dispersal by flying is rare or only occurs over a short distance and daughter queens often remain with the mother colony. Budding (splitting of a nest into several daughter nests) results in oligo- to polydomous colonies and the extension of foraging activities throughout an entire forest.

Consequently, mono-/oligogynous species with monodomous colonies are likely to be better at colonizing fragmented habitats, whereas a polygynous species with polydomous colonies (dispersing by budding) are better at colonizing areas where the habitat patches are connected (Mabelis, 1994). Indeed, the distribution of both species and their colony structure very often coincides with these two strategies in the Netherlands, eastern Germany and Poland (Seifert, 1991; Mabelis, 1994). This general pattern is far less clear in the northern part of Belgium. In the north-western area of Belgium, near Bruges, four types of red wood ant colonies can be found: mono- and polydomous $F$. rufa and mono- and polydomous $F$. polyctena, which occur in both large and small, highly fragmented woodlands.

The aims of our study are:

(1) To give an overview of the present distribution of red wood ants in north-western Belgium and quantify the habitat preferences of the four types of red wood ants;

(2) To compare the changes in the distribution of species of the Formica rufa group over the last two decades;

(3) To compare the environmental and landscape variables at sites previously and currently occupied by these ants;

(4) To formulate policy for managing forests that favour red wood ants that take into account the high degree of fragmentation of present day woodlands.

\section{MATERIAL AND METHODS}

\section{Study area}

The current distribution of species of red wood ant in the northern part of Belgium (Flanders) is well known (Dekoninck et al., 2003; Loones et al., 2008). Recent distribution maps for the 3 species studied indicate that viable populations only occur in the sandy regions in the north-east (Campine region; 3 species) and north-west (near Bruges; 2 species) of Flanders (Dekoninck et al., 2003). In the north-west nests of Formica polyctena and F. rufa are found at the border between woodland and dry heathland or dry nutrient poor grassland vegetation (with Cytisus scoparius L., Calluna vulgaris L. and Erica cinerea L.) in open patches in the woodland or along the edges of woodland mainly dominated by Quercus robur L. and Pinus sylvestris L.. Although still present, these open thermophilic habitats are small and threatened by forest succession and human disturbance, i.e. urbanisation (roads and buildings), intensive agriculture (fertilisers, pesticides) and recreation (Piessens et al., 2004, 2005). The study area covers $20 \times 55 \mathrm{~km}(445$ $\mathrm{km} \times 5 \mathrm{~km}$ UTM grid cells).

\section{Inventory and habitat characterisation of present red wood ant sites}

All sites with colonies of the Formica rufa group, hereafter called wood ant sites or WAS, were recorded in the study area in 2007 and 2008 during the period when ants are most active (May-September). Colonies consisted of only one nest (monodomous) or of a group of nests connected by workers running from one nest to another (polydomous colonies). On this basis, four types of red wood ant colonies: "rufa monodomous", "rufa polydomous", "polyctena monodomous" and "polyctena polydomous" were identified and mapped in Arcview3.1 (Fig. 1), and the presence or absence of Serviformica species noted. A zone of $\varnothing 100 \mathrm{~m} / 31400 \mathrm{~m}^{2}$ was designated around the centre of each WAS. This zone is approximately the area potentially foraged by a red wood ant colony (Mabelis, 2002; Maki-Petäys et al., 2005). The percentage of the area in each zone covered with oak, beech, other deciduous woodland, coniferous woodland (mainly Pinus sylvestris), shrubs and hedgerows, heathland (including also dry nutrient poor grassland), agricultural grassland and arable fields, roads, industrial plants and urbanised areas was calculated using the Biological Valuation Map of 2008 (a database with biotopes covering the whole of Flanders; BWK version 2008 see De Saeger et al., 2008). In addition to these environmental variables the total area of woodland and the length of the southern, south eastern and south western exposed woodland margins were calculated for each WAS. Northern, north eastern and north western woodland edges were not considered as they are neither favoured foraging areas or nesting sites (Loones et al., 2008).

\section{Inventory and habitat characterisation of former red wood ant sites}

At the end of the 1980s and beginning of the 1990s there was an identical habitat type mapping of this region using an older version of the Biological Valuation maps for Flanders (1986-1996, BWK version 1.0, see De Blust et al., 1994; Wils et al., 2004). In addition, there is a record of the locations of 44 red wood ant colonies present at that time. It is unknown whether these colonies belonged to $F$. rufa or $F$. polyctena. During the summers of 2007 and 2008 all these sites were revisited and if a colony was still present, it was designated an old wood ant site (OWAS). If a thorough search of each locality and the surrounding area within a radius of $200 \mathrm{~m}$ failed to a colony, the site (30) was designated a former wood ant site (FWAS). As for the WAS we inspected each FWAS and OWAS for the presence of Serviformica-species.

\section{Potential causes of loss and threats}

After visual inspection of each FWAS the factors that may have caused the extinction of the colony were assigned to the following categories: (a) shrubs or canopy of trees have over- 

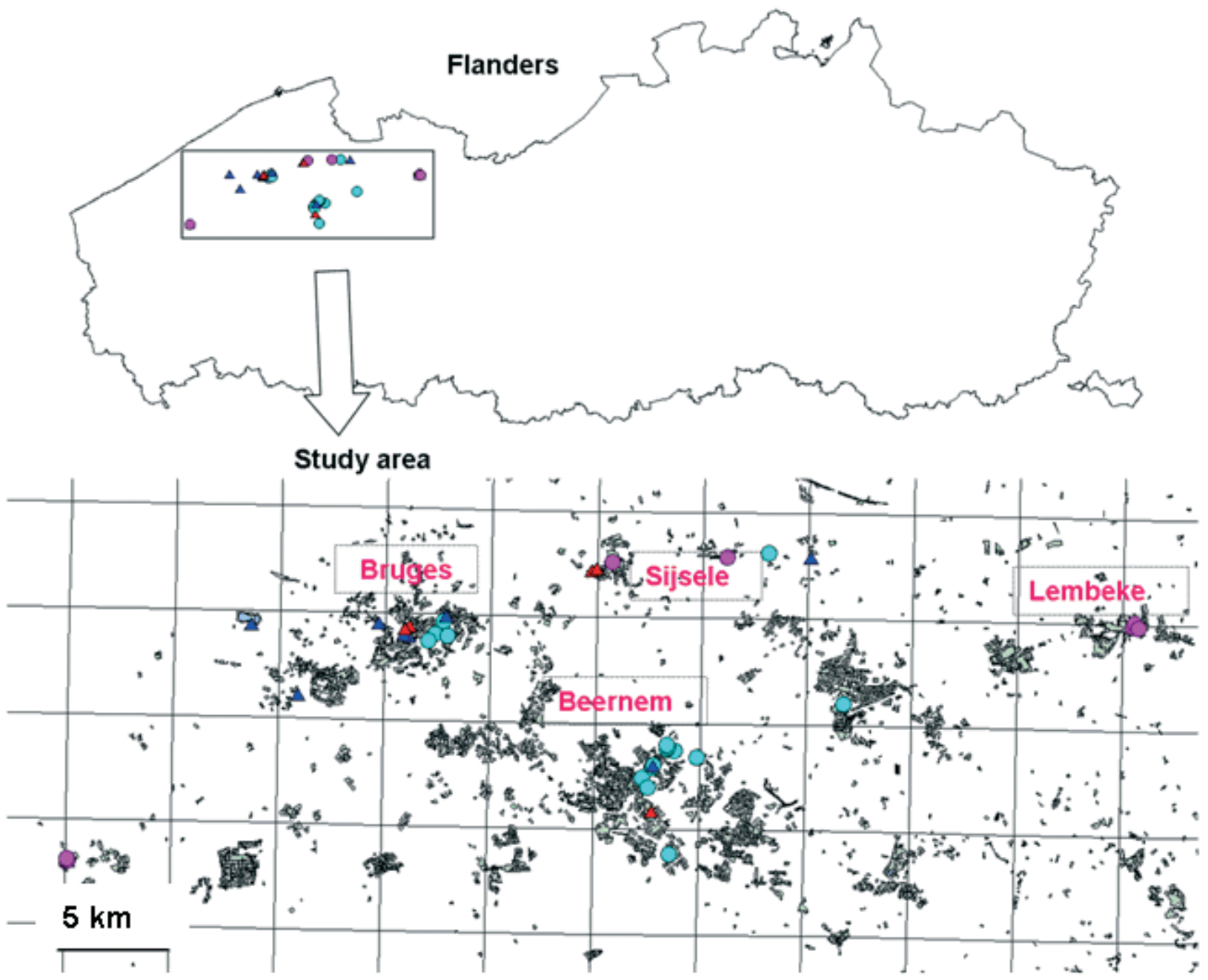

Fig. 1. Study area in north-western Belgium with woodland patches and the 36 red wood ant sites present in 2007-2008. Formica rufa monodomous colonies are pink $\bullet, F$. rufa polydomous colonies red $\boldsymbol{\Lambda}, F$. polyctena monodomous light blue $\bullet$ and $F$. polyctena polydomous blue $\mathbf{\Lambda}$. Squares are $5 \mathrm{~km} \times 5 \mathrm{~km}$ UTM grid cells.

grown the nests and reduced the amount of solar radiation reaching ground level; (b) nearby intensive agricultural activity (manure, pesticides), (c) intensive recreation (trampling, mountain biking), (d) urbanisation (nearby recent new buildings) and (e) removal of trees that are used by ants as a source of food (forest thinning or clear-cutting). Each category is coded as either present or absent (i.e. binary). The same categories were used to describe the threats at each WAS and OWAS.

\section{Data analyses}

Principal component analysis (PCA) was used to investigate differences in the habitats in terms of the 12 habitat variables measured around WAS and FWAS. To test whether the position of the four types of red wood ant nests differed in the PCA diagram, and hence whether these environmental and landscape characteristics of the sites differed among these four types, a Kruskal Wallis Anova of the PCA scores and Mann-Whitney U tests with Bonferonni correction for post hoc pairwise comparisons were used.

Mann-Whitney $U$ tests were also used to determine if the four types of red wood ant differed in their association with any of the twelve habitat variables, and detect changes that might have occurred in these variables between 1986-1996 and 2008 in the zones around each of the FWAS and OWAS.

\section{RESULTS}

\section{Present conservation status of red wood ants near Bruges}

The positions of 36 red wood ant colonies were mapped, which sums to a total of 61 nests (Fig. 1). As this survey included most of the suitable habitats in the area, it is likely this is the present number of colonies. Twelve colonies belonged to the species $F$. rufa $(33 \%)$ of which 5 were monodomous and 7 polydomous (on average 3.6 nests/colony). Serviformica species were present at all these sites.

There were 16 monodomous populations and 8 polydomous populations (20 nests and an average of 2.2 nests per population) of $F$. polyctena. Serviformica were recorded at all but one of the sites of the polydomous colonies.

Differences between $F$. rufa and $F$. polyctena in their association with woodland area and length of woodland edges

Zones in which there were $F$. rufa $(\mathrm{n}=12)$ contained significantly more woodland (sum of all deciduous and 

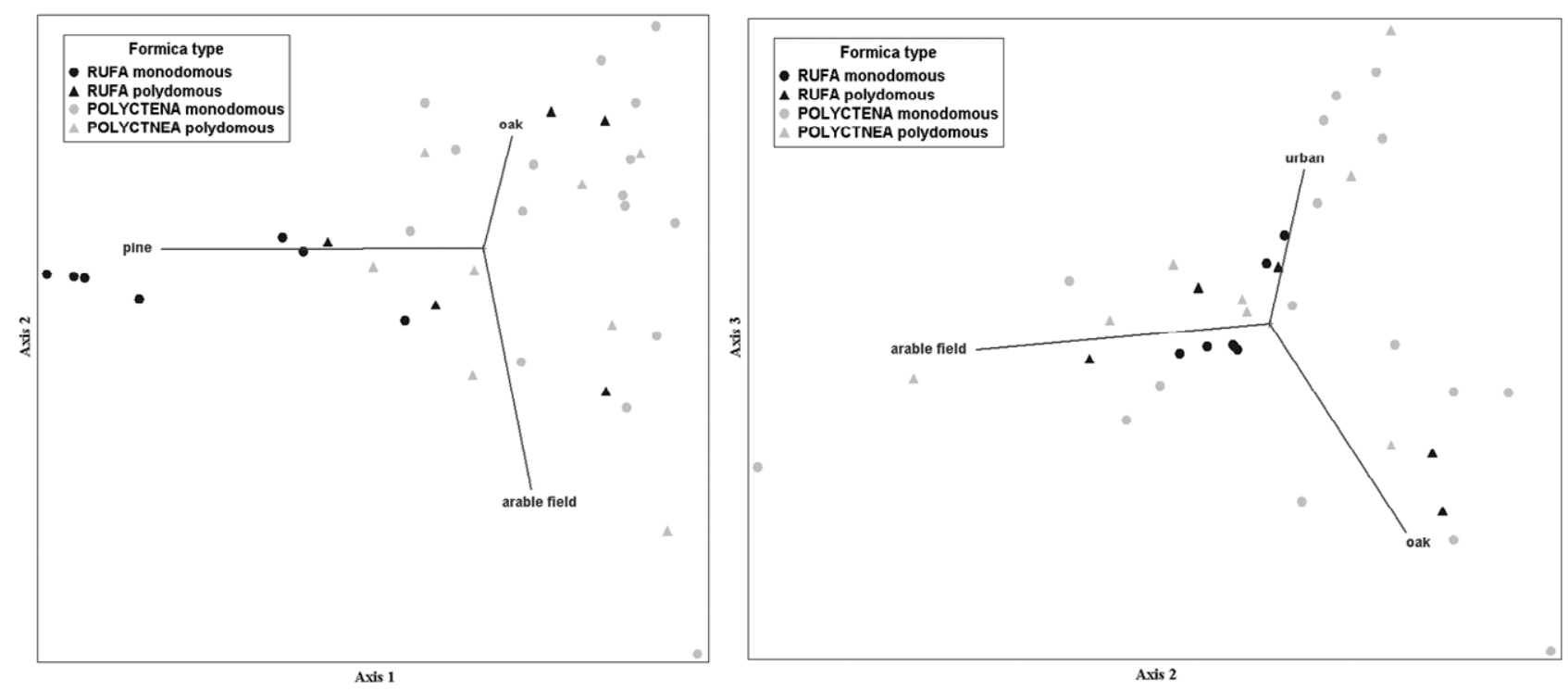

Fig. 2. PCA diagrams of the 12 habitat type variables in zones around 36 red wood ant populations in north-western Belgium. The type of red wood ant: $\bullet$ monodomous and $\boldsymbol{\Delta}$ polydomous. Black symbols indicate $F$. rufa and grey $F$. polyctena. (left figure Axis 1 vs Axis 2, right figure Axis 2 vs Axis 3).

Pinus woodland, Mann-Whitney $\mathrm{U}$ test $\mathrm{df}=1, \mathrm{Z}=2.819$ and $\mathrm{p}=0.005)$, had a greater length of southern exposed woodland edges (Mann-Whitney $\mathrm{U}$ test $\mathrm{df}=1, \mathrm{Z}=2.50$ and $\mathrm{p}=0.012)$ and greater total length of woodland edges (Mann-Whitney $\mathrm{U}$ test $\mathrm{df}=1, \mathrm{Z}=2.819$ and $\mathrm{p}=0.005$ ) than those with $F$. polyctena $(\mathrm{n}=24)$.

The apparent preference of $F$. rufa is mainly for large areas of pine forest (Mann-Whitney $\mathrm{U}$ test $\mathrm{df}=1, \mathrm{Z}=$ 3.59 and $\mathrm{p}=0.0003) . F$. polyctena colonies occurred in zones that included significantly more urban land (MannWhitney $\mathrm{U}$ test $\mathrm{df}=1, \mathrm{Z}=2.18$ and $\mathrm{p}=0.0211$ ).

Differences in the habitats occupied by the four types of red wood ants

The four types of red wood ant differed significantly in their association with the percentage of the area covered with woodland (Kruskal-Wallis test $\mathrm{H}(3, \mathrm{~N}=36)=$ $11.66, p=0.0087)$. Post hoc Mann-Whitney U tests indicate significant differences in the associations with total coverage of woodland between monodomous $F$. rufa and monodomous $F$. polyctena $(\mathrm{Z}=2.819$ and $\mathrm{p}=0.0047)$, with a greater chance of monodomous $F$. rufa occurring in zones with a high total coverage of woodland. Results of the Kruskal-Wallis ANOVA revealed no significant variation in their association with total length of south exposed woodland edge and total length of woodland edge (Kruskal-Wallis test $\mathrm{H}(3, \mathrm{~N}=36)=11.66, \mathrm{p}>$ $0.05)$.

The PCA diagram based on the 12 habitat variables recorded in the zones around the 36 WAS (Fig. 2) shows that the area cover with coniferous woodland is significantly correlated with the first principal component (39.84\% of the total observed variance in the dataset) (Spearman rank correlation: coniferous woodland $\mathrm{r}=$ $-0.976, \mathrm{n}=36$ and $\mathrm{p}<0.01)$. Results of the KruskalWallis ANOVA revealed significant variation in the position of the different types of red wood ants along the first axis (Kruskal-Wallis test $\mathrm{H}(3, \mathrm{~N}=36)=14.04, \mathrm{p}=$ 0.0028). Post hoc Mann-Whitney $U$ tests indicate that monodomous $F$. rufa are significantly more associated with woodlands with a high proportion of coniferous trees than either monodomous $(Z=4.168$ and $p=0.0002)$ or polydomous $F$. polyctena $(\mathrm{Z}=2.928$ and $\mathrm{p}=0.0204)$.

Cover of oak, arable fields and other deciduous woodland were significantly correlated with the second principal component, which additionally explained $19.43 \%$ of the total observed variance in the dataset (Spearman rank correlation: oak $\mathrm{r}=0.519, \mathrm{n}=36$ and $\mathrm{p}<0.01$; arable field $\mathrm{r}=-0.699, \mathrm{n}=36$ and $\mathrm{p}<0.01$ ). Results of the Kruskal-Wallis ANOVA revealed no significant difference in the position of red wood ant types along the second axis (Kruskal-Wallis test $\mathrm{H}(3, \mathrm{~N}=36)=3.516$, $\mathrm{p}$ $=0.32$ ).

The cover of urban land and oak were significantly related to the third principal component, which explained some additional 13.08 of the total observed variance in the dataset (Spearman rank correlations: urban land $\mathrm{r}=$ $0.448, \mathrm{n}=36$ and $\mathrm{p}<0.01 ;$ oak $\mathrm{r}=-0.711, \mathrm{n}=36$ and $\mathrm{p}$ $<0.01$; other deciduous woodland $\mathrm{r}=0.437, \mathrm{n}=36$ and $\mathrm{p}$ $<0.01)$. Results of the Kruskal-Wallis ANOVA revealed no significant variation in types of red wood ant along the third axis (Kruskal-Wallis test $\mathrm{H}(3, \mathrm{~N}=36)=1.95999$, both $\mathrm{p}=0.5808$ ).

\section{Inventory of FWAS}

Quantifying the loss of red wood ant populations

From 1984 to 2000 red wood ant sites were recorded in 27 different $1 \mathrm{~km} \times 1 \mathrm{~km}$ UTM grid cells $(\mathrm{n}=44$ colonies; Fig. 3). Of the 44 colonies mapped at the end of last century only $14(32 \%)$ were found in 2007-2008. At one $(9 \%)$ of the 14 OWAS, Serviformica appeared to be extinct. Serviformica species appeared to be extinct in 21 $(70 \%)$ of the 30 sites that were previously occupied by red wood ants (= FWAS). 


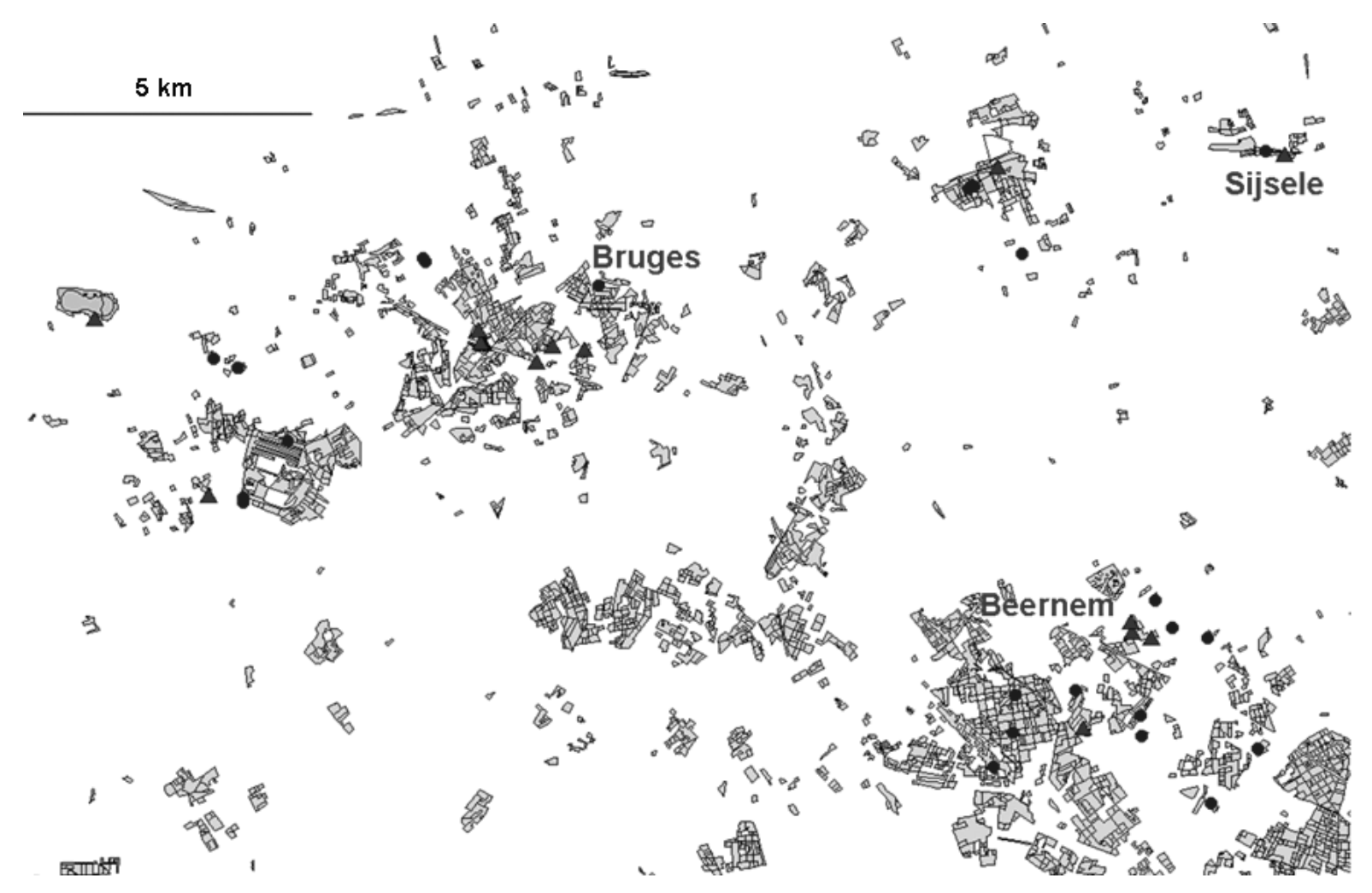

Fig. 3. Study area in north-western Belgium with sites $(\bullet)$ where red wood ants occurred at the end of previous century (former wood ant sites, FWAS). Sites ( $\mathbf{\Lambda})$ where wood ants are currently present (called OWAS). Grey patches indicate woodland.

Changes in the habitat that occurred between the 80 s and 90s of last century and 2008

There were no significant changes in areas covered by the 12 different vegetation categories, the total length of south exposed woodland edge and total area of woodland, which appeared to contribute significantly to the decline (all Mann-Whitney U tests between FWAS and OWAS, p all $>0.05)$.

The average area of woodland in a zone around a FWAS changed from $47.3 \%$ when red wood ants were previously present to $47.1 \%$. In zones around each OWAS the average area changed from $50.2 \%$ to $48.2 \%$. The average of the total length of south, south east and south west exposed woodland edges at FWAS changed from 156 to $190 \mathrm{~m}$ and from 226 to $270 \mathrm{~m}$ at OWAS. The total length of woodland edges (including also northern, western and eastern exposed edges) increased form 224 to $388 \mathrm{~m}$ at FWAS and from 277 to 468 at OWAS.

\section{FWAS and WAS}

The second PCA searched for correlations among the 12 vegetation and habitat variables in the zones around WAS and FWAS, using Nature Valuation maps for 2008. When the 66 sites (30 FWAS and 36 WAS: 4 types of red wood ants) and significant vegetation variables are plotted (Fig. 4), the area covered by coniferous woodland was significantly related to the first principal component, which explains $31.18 \%$ of the total observed variance in the dataset (Spearman rank correlation: pine $r=0.956, n$ $=80$ and $\mathrm{p}<0.001)$. Results of the Kruskal-Wallis ANOVA revealed significant variation in red wood ant populations for the first axis (Kruskal-Wallis test H (3,N $=80)=25.156, p=0.00001)$. Post hoc Mann-Whitney $U$ tests indicate a significantly higher cover of coniferous woodland in zones around sites with monodomous $F$. rufa than those with monodomous $F$. polyctena $(\mathrm{Z}=$ 4.7429 and $\mathrm{p}=0.00002)$ and polydomous $F$. polyctena $(\mathrm{Z}$ $=2.927$ and $\mathrm{p}=0.03421)$, and those sites where wood ants are no longer present $(Z=4.2473$ and $p=0.0076)$.

The cover of arable fields, urban land and oak were significantly related to the second principal component, which additionally explained $19.03 \%$ of the total observed variance in the dataset (Spearman rank correlations arable field $\mathrm{r}=0.789, \mathrm{n}=80$ and $\mathrm{p}<0.001$; urban land $\mathrm{r}=-0.507, \mathrm{n}=80$ and $\mathrm{p}<0.001$; oak $\mathrm{r}=-0.425, \mathrm{n}=$ 80 and $\mathrm{p}<0.001)$. Results of the Kruskal-Wallis ANOVA revealed no significant variation in red wood ant populations for the second axis (Kruskal-Wallis test $\mathrm{H}$ $(3, \mathrm{~N}=80)=3.148380, \mathrm{p}=0.5333)$.

\section{Potential causes of local extinction and current threats}

Intensive agriculture and shading by shrubs and trees appear to be the main factors responsible for the extinction of many red wood ant colonies in the region (for FWAS both account for $26.7 \%$, see Table 1). For the WAS and OWAS threat from intensive agricultural activities are less important, mainly because there are no populations near agricultural fields. Shading (64.3\%) and recreation $(21.4 \%)$ are the most important threats to OWAS and shading the most important threat to WAS $(36.4 \%)$. There are no obvious threats at present for only a few colonies. 

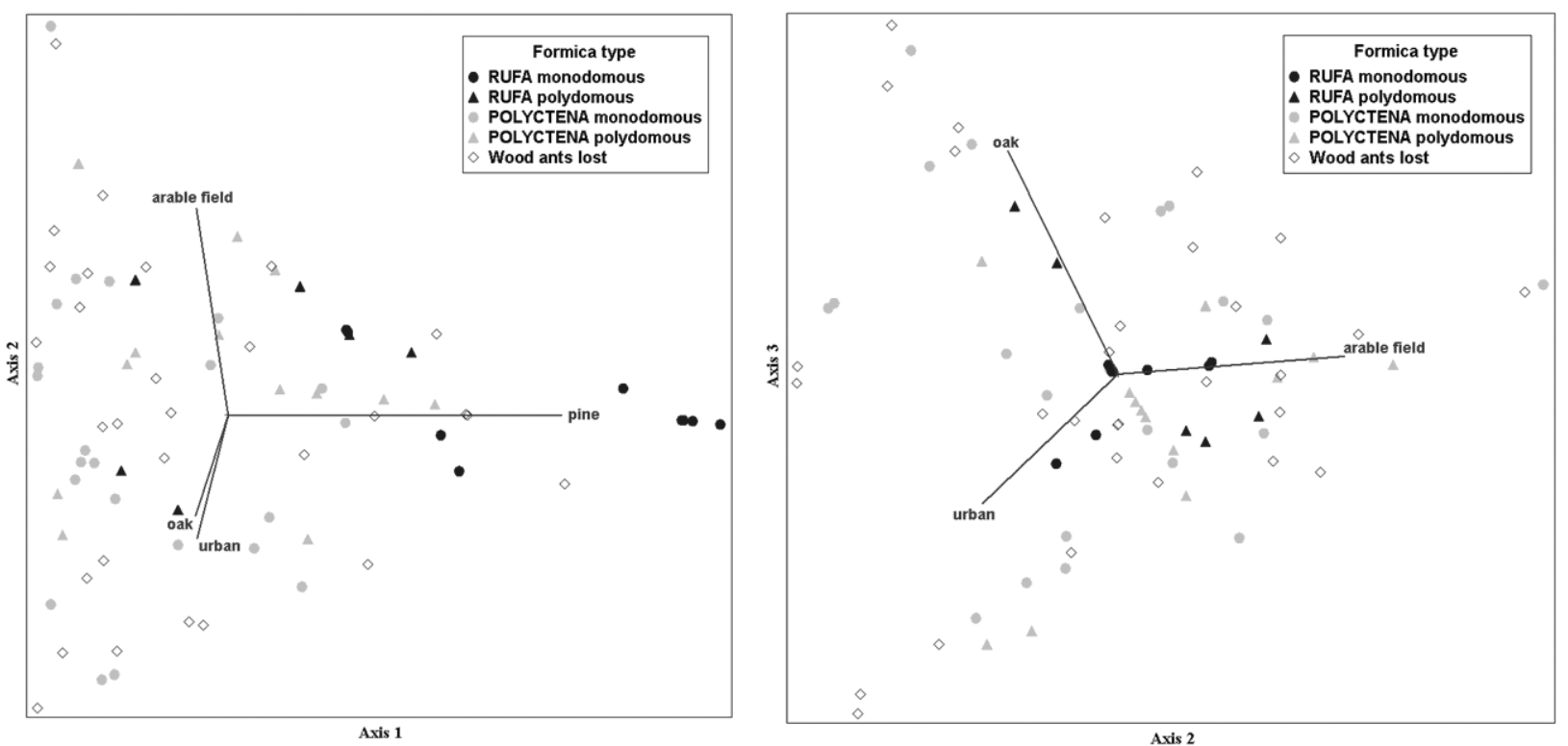

Fig. 4. PCA diagrams of the 12 vegetation variables measured in zones around 36 WAS and 30 FWAS in north-western Belgium. The type of red wood ant: $\bullet$ monodomous and $\boldsymbol{\Delta}$ polydomous. Black symbols indicate $F$. rufa, grey $F$. polyctena and $\diamond$ sites where red wood ants became extinct (left figure Axis 1 vs Axis 2, right figure Axis 2 vs Axis 3).

\section{DISCUSSION}

\section{Differences in habitats occupied by colonies of the four types of red wood ant}

In north-western Belgium there are four types of red wood ant populations: mono- and polydomous $F$. rufa (always 3 mounds or more) and mono- and polydomous $F$. polyctena. Although a monodomous colony structure is usual for $F$. rufa (Seifert, 1991, 2007), a polydomous colony structure appears to be common in Flanders (Dekoninck et al., 2003; Dekoninck \& Muls, 2005; Loones et al., 2008) and other parts of Europe (Skinner, 1980; Seifert, 1991, 2007). These polydomous colonies each have several queens (e.g. Skinner, 1980; Rosengren \& Pamilo, 1983; Dekoninck et al., unpubl. data). As reported elsewhere (Dekoninck et al., 2008; Loones et al., 2008) the number of nests in these Flemish polydomous colonies can fluctuate from year to year and so does the

TABle 1. Probable causes of extinction of wood ants at 30 former wood ant sites (FWAS) and the threats to 14 OWAS (old wood ant sites) and 22 WAS (wood ant sites) in percentages and absolute numbers.

\begin{tabular}{lccc}
\hline & $\begin{array}{c}\text { FWAS } \\
(\mathrm{n}=30)\end{array}$ & $\begin{array}{c}\text { OWAS } \\
(\mathrm{n}=14)\end{array}$ & $\begin{array}{c}\text { WAS } \\
(\mathrm{n}=22)\end{array}$ \\
\hline (a) shading & $26.7(8)$ & $64.3(9)$ & $36.4(8)$ \\
(b) agriculture & $26.7(8)$ & $7.1(1)$ & $13.6(3)$ \\
(c) recreation & $16.7(5)$ & $21.4(3)$ & $9.1(2)$ \\
(d) nearby urbanisation & $13.3(4)$ & 0 & $4.5(1)$ \\
(e) removal of food trees & $3.3(1)$ & 0 & $4.5(1)$ \\
(a) $+(b)$ & $6.7(2)$ & 0 & $9.1(2)$ \\
(a) $+(\mathrm{c})$ & $6.7(2)$ & 0 & $4.5(1)$ \\
(a) $+(\mathrm{c})+(\mathrm{d})$ & 0 & $7.1(1)$ & 0 \\
(a) $+(\mathrm{d})$ & 0 & 0 & $4.5(1)$ \\
No threats & 0 & 0 & $13.6(3)$ \\
\hline
\end{tabular}

number of queens. Monodomous colonies of $F$. polyctena are less common in Europe (Seifert, 1991, 2007; Gyllenstrand et al., 2004; Maebe, 2007). In the study area, 16 of the $24(66 \%)$ colonies of this species are monodomous. Personal observations indicate that these monodomous nests are polygynous.

On average, the $F$. rufa colonies are situated furtherest from urbanised areas and roads. Moreover, the structure of the colonies is dependent on the environment. Monodomous $F$. rufa colonies almost exclusively occurred in forests dominated by coniferous trees (Pinus sylvestris), which appears to be a suitable habitat for this type of red wood ant. Such forests have an open structure and the nest mounds are located in areas where direct sunlight reaches the ground. Aphid colonies on Pinus sylvestris (Cinara sp.) are sometimes very abundant in these woodlands, with Cinara pini and $C$. schimitscheki being the most abundant aphids. The density of nest of Serviformica in this type of woodland is not only high at the edges but $F$. fusca can also make nests in the centre of these open forests.

The other three types of red wood ant are associated with less forest cover, and often occur close to agricultural land and human settlements, which mainly consists of deciduous trees. The colonies that recently went extinct were in the same kind of forest (Fig. 4). On heathland surrounded by oak and shrubs the probability of finding polydomous $F$. rufa and monodomous and polydomous $F$. polyctena is greater than finding monodomous $F$. rufa. This habitat is highly threatened in north-western Belgium and nowadays confined to small nature reserves (Piessens et al., 2004, 2005).

\section{Dispersal strategy and social organisation}

Red wood ants are absent in the majority of woodland patches (Fig. 1). No newly founded colonies were located 
in the areas surrounding FWAS. The absence or loss of red wood ants may be the result of poor habitat quality. The probability of colonization is likely to be very low if these sites are isolated from other occupied areas (Mabelis, 2007). Red wood ant species differ in their ability to colonize vacant areas, due to differences in their dispersal strategies (Seifert, 1991, 2007; Höfener et al., 1996). The difference is associated with the readiness of workers to accept more queens into their nest, either fertilized daughters or young queens from other nests. In many cases a colony of a species that accepts many queens, like $F$. polyctena, has a lower probability of going locally extinct than a colony of a species that accepts just one or only a few queens (Mabelis \& Chardon, 2006), like F. rufa. Moreover, a species that has many queens per nest can disperse by means of budding, during which workers transport several queens form the mother nest to newly built daughter nests. In such cases stable super-colonies can develop as are known for Formica aquilonia (Sorvari \& Hakkarainen, 2005), Formica paralugubris and Formica lugubris (Cherix, 1980; Gyllenstrand \& Seppä, 2003) and Formica truncorum (Bargum et al., 2004). This is often a much safer and easier but slower way of dispersal than colonizing an area by means of flying queens (Rosengren \& Pamilo 1983, Rosengren et al., 1993; Mabelis, 1994). However, the advantage of dispersal by budding is lost if the habitat consists of small patches. In this case, it may be a better option for a young queen to leave the area by flying (Höfener et al., 1996; Mabelis \& Korczyńska, 2001; Mabelis, 2007). In the study area, both $F$. rufa and $F$. polyctena, had flexible social organizations and dispersal strategies. The formation of polydomous colonies was not associated with large forest patches (more than $1 \mathrm{~km}^{2}$ ). Moreover, there were indications that all 4 types of red wood ant nests are frequently polygynous (Dekoninck, unpubl. data). Probably small woodland patches often change in quality, accessibility and presence of Serviformica-species and as a result in the absence of a species-fixed organisation and dispersal strategy.

\section{A high risk for extinction}

As $68 \%$ of the red wood ant colonies recorded at the end of the last century no longer exist there seems to be a real danger of these ants going extinct in this region. The absence of Servifomica ants at $64 \%$ of the FWAS means these sites are unlikely to be re-colonized. At present red wood ants are only likely to be safe in large forest complexes and nature reserves in the region, where the even more threatened myrmecophiles, Clytra quadripunctata and Coccinella magnifica occur (Decock, 2006; Dekoninck et al., 2008). It is difficult to ascertain if the extinction rates of the four types of red wood ant differed because neither the species or type of red wood ant present at the end of the last century were recorded.

\section{Reasons for extinction}

Because there were no apparent differences in the composition of the habitat in the designated zone around each of the colonies that went extinct and those that are still extant, the disappearance of so many colonies cannot be due to the loss of suitable habitat. Field observations made during 2007 and 2008 indicate that habitat deterioration due to disturbances is the likely cause. A combination of the loss of sufficient appropriate food sources (Puntilla, 1996), repeated human disturbance by agricultural activities (Mabelis, 2002) and recreation, succession of several wet summers (Robinson, 2001) and habitat fragmentation, can prove fatal for many red wood ant colonies (Bernasconi et al., 2005; Mäki-Petäys et al., 2005).

Most of these disturbance factors occur in this region (Table 1). Of greatest importance is the shading of the nests that occurs due to overgrowth by shrubs and closing of the tree canopy. Also important is the intensive use of the forests for recreation and nearby intensive agriculture. Drift of manure and pesticides from sprays applied to fields often contaminates nests in woodland verges adjacent to agricultural land.

The high degree of fragmentation and disturbance typical of woodlands in this region appears to have little effect on Formica polyctena (both monodomous and polydomous). About $60 \%$ of all nests and $70 \%$ of all colonies in the study area are of this species. As $F$. polyctena forms almost exclusively polygynous colonies (Seifert, 2007) this species is probably more resistant to shading or intensive agricultural activities than the monodomous and in many cases monogynous $F$. rufa. If at least one nest of a polygynous colony survives a disturbance, the "back-up queens" in the surviving mound can restore the colony. Maybe this is why both $F$. rufa and $F$. polyctena near Bruges are polygynous, even those producing monodomous nests (Dekoninck, unpubl. data).

\section{Is Serviformica the missing link?}

While only in one out of $36(<3 \%)$ WAS no Serviformica ants were detected during our intensive field surveys of 2007 and 2008, these host ants could not be found in $70 \%$ of the FWAS. These results indicate there is a link between the extinction of red wood ant colonies and either the absence or an extremely low density of Serviformica ants. Indeed, when $F$. fusca is absent or there are very few nests, re-colonization by temporary parasitism is very unlikely (cf. Rosengren \& Pamilo, 1983; Puntilla, 1996). The only remaining option then is migration over the ground by budding (Mabelis, 1984). This is a highly unlikely mode of dispersal in our region because of the high degree of fragmentation and isolation of the woodlands. Seifert $(1986,2007)$ documents the high susceptibility of Serviformica to shading. The reduction in host nest availability, due to closure of the higher vegetation layers and anthropogenic disturbance, may therefore contribute to the extinction of red wood ant colonies. Future investigations should determine whether the development of a grass layer is due to atmospheric and agricultural nitrogen precipitation and the effect thus may have had in reducing the abundance of Serviformica.

Moreover, many woodland patches are too small to maintain high nest densities of Formica fusca and red wood ants. In small WAS sometimes Serviformica suffer 
from extreme aggression and competition from the bigger and usually more abundant red wood ant workers (Mabelis, 1984; Czechowski \& Vepsäläinen, 1999; Czechowski \& Markó, 2006). If this leads to the extinction of Serviformica, red wood ants create for themselves a "presuicidal" situation. In many such cases "once lost" can mean "lost forever". In the open coniferous woodland Serviformica is still abundant and monodomous $F$. rufa colonies thrive.

\section{Conservation of red wood ants}

Increasing and improving the connectivity of woodland patches is highly recommended for the sustainable conservation of red wood ants in this region. Much more important is to maintain what is left of their preferred habitat. The remaining colonies need to be protection.

In Belgium, red wood ants prefer to build their nests in open forests and on the (southern) edges of dense forests. Like many other social insects, most species of ants use the warmth of the sun to increase the rate of development of the brood in the nest (Hölldobler \& Wilson, 1990). Under natural conditions small open areas can result from windfall, and grazing by big herbivores sometimes can keep such areas open long enough for forest edge species, like the red wood ants, to become established (Mabelis, 2007; Kilpeläinen et al., 2008). In Europe, the forests are mainly used for producing wood (Kilpeläinen et al., 2005). For red wood ant conservation in these forests, open areas can be created by felling trees or pulling them down. This would not only create a habitat for red wood ants but also for the necessary Serviformica as Formica fusca, and many other open-forest species (Dajoz, 2000; Grove, 2002). Thus, by creating a more varied vegetative structure and small open areas in forests it should be possible to maintain or increase the biodiversity (Baz \& Garcia-Boyero, 1995).

Thus, there is a need to establish zones specifically for conserving red wood ant colonies outside nature reserves and large open forests. Formica colonies near to areas of intensive agriculture would benefit from the presence of an unprocessed border along the edges of adjoining pasture or arable fields. The management of woodland edges should aim to increase the amount of solar radiation reaching the soil surface. It is also important to monitor the effect of these measures on both red wood ant colonies and the presence and abundance of Serviformica ants. In summary, conservation of red wood ants in the study area is not a lost cause but there is an urgent need to protect the preferred habitats of the ants.

ACKNOWLEDGEMENTS. We want to thank P. Jonckheere for identifying the localities of colonies of red wood ants he mapped near Bruges during the 1980s and 1990s. Many volunteers and conservators of nature reserves helped us complete this inventory of present day colonies. We are grateful to A.A. Mabelis, B. Seifert, J. Mertens, J. Billen, D. Bonte \& P. Breyne for comments on an earlier version of the manuscript. J.-P. Maelfait died during the writing of this publication and we sincerely thank him for all the knowledge and enthusiasm he passed on to us and many other entomologists in Belgium and elsewhere during many years of collaboration.

\section{REFERENCES}

AdLunG K.G. 1966: A critical evaluation of the European research on use of red wood ants (Formica rufa group) for the protection of forests against harmful insects. Z. Angew. Entomol. 57: 167-189.

Bargum K., Boomsma J.J. \& Sundström L. 2004: A genetic component to size in queens of the ant, Formica truncorum. Behav. Ecol. Sociobiol. 57: 9-16.

BAz A. \& Garcia-Boyero A. 1995: The effects of forest fragmentation on butterfly communities in central Spain. J. Biogeogr. 22: 129-140.

Bernasconi C., Maeder A., Cherix D. \& Pamilo P. 2005: Diversity and genetic structure of the wood and Formica lugubris in unmanaged forests. Ann. Zool. Fenn. 42: 189-199.

Cherix D. 1980: Note préliminaire sur la structure, la phenologie et le régime alimentaire d'une super-colonie de Formica lugubris Zett. Insectes Soc. 27: 226-236.

Collingwood C.A. 1979: The Formicidae (Hymenoptera) of Fennoscandia and Denmark. Fauna Entomol. Scand. 8: $1-175$.

Czechowski W. \& Marko B. 2006: Uncomfortable protection: Formica polyctena Först. Shelters Formica fusca L. from Formica sanguinea Latr. (Hymenoptera: Formicidae). Ann. Zool. (Warszawa) 56: 539-548.

Czechowski W. \& VepsäLÄInen K. 1999: Plesiobiosis between Formica fusca L. and Formica aquilonia Yarr. (Hymenoptera, Formicidae). Ann. Zool. (Warszawa) 49: 125-127.

DAJOz R. 2000: Insects and Forests. The Role and Diversity of Insects in the Forest Environment. Intercept, London, Paris, New York, 668 pp.

De Blust G., Paelinckx D. \& Kuijken E. 1994: Up-to-date information on nature quality for the environmental management in Flanders. In Klijn F. (ed.): Ecosystem Classification for Environmental Management. Kluwer Academic Publishers, Dordrecht, Boston, London, pp. 223-249.

De Bruyn G.J., Goosen-De Roo L., Hurbergtse van den Berg A.I.M. \& FEIJEN H.R. 1972: Predation of ants by woodpeckers. Ekol. Pol. 20: 83-91.

DECOCK L. 2006: Rode bosmieren en het schitterend lieveheersbeestje Coccinella magnifica in West-Vlaanderen. [Red Wood Ants and Coccinela magnifica in Western Flanders.] Master thesis, Ghent University, 147 pp. [in Dutch].

DeKoninck W. \& Muls D. 2005: Kale behaarde, of harige kale rode bosmieren in Elewijt? [Bold hairy or hairy bold red wood ants in Elewijt?] Jaarboek BRAKONA 2005: 6-10 [in Dutch].

Dekoninck W., Vankerkhoven F. \& Maelfait J.-P. 2003: Verspreidingsatlas en voorlopige Rode Lijst van de mieren van Vlaanderen. Rapport van het Instituut voor Natuurbehoud 2003.07. [Atlas of Distribution and a Provisional Red List of the Ants of Flanders. Report of the Institute of Nature Conservation (Series B) 2003.07.] Brussel, 191 pp. [in Dutch, English abstr.].

Dekoninck W., Loones J. \& Maelfait J.-P. 2008: De Rode bosmieren van de Sixtusbossen krijgen bezoek. [Visitors for the red wood ants of the Sixtusbossen.] De Bron 16(63): 28-31 [in Dutch].

De Saeger S., Paelinckx D., Demolder H., Denys L., Packet J., Thomaes A. \& Vandekerkhove K. 2008: Sleutel voor het karteren van NATURA2000 habitattypen in Vlaanderen, grotendeels vertrekkende van de karteringseenheden van de Biologische Waarderingskaart. Versie 5 juni 2008. [Key to Survey the Natura 2000 Habitats in Flanders, Based on Maps of the Biological Validation Map. Version 5 June 2008.] INBO.IR.2008.23, 49 pp. [in Dutch]. 
Domisch T., Finér L. \& Jurgensen M.F. 2005: Red wood ant mound densities in managed boreal forests. Ann. Zool. Fenn. 42: $277-282$.

Gorb S.N. \& Gorb E.V. 1995: Removal rates of seeds of five myrmecochorous plants by the ant Formica polyctena (Hymenoptera: Formicidae). Oikos 73: 367-374.

GösswaLD K. 1952: Über Versuche zur verwendung von Hilfameisen zwecks vermeehrung der Nützlichen kleinen Roten Waldameise. Z. Angew. Entomol. 34: 1-44.

Grove S.J. 2002: Insects and forests: The role and diversity of insects in the forest environment (book review). J. Insect Conserv. 6: 69-70.

Gyllenstrand N. \& SepPÄ P. 2003: Conservation genetics of the wood ant, Formica lugubris, in a fragmented landscape. Mol. Ecol. 12: 2931-2940.

Gyllenstrand N., Seppä P. \& Pamilo P. 2004: Genetic differentiation in sympatric wood ants, Formica rufa and Formica polyctena. Insectes Soc. 51: 139-145.

Hawes C., Stewart A.J.A. \& Evans H.F. 2002: The impact of wood ants (Formica rufa) on the distribution and abundance of ground beetles (Coleoptera: Carabidae) in a Scots pine plantation. Oecologia 131: 612-619.

HÖfEner C., Seifert B. \& KRÜGer T. 1996: A genetic model for disruptive selection on colony social organisation, reproduction, and ecotype distribution in wood ants inhabiting different woodland habitats. Insectes Soc. 43: 359-373.

Hölldobler B. \& Wilson E.O. 1990: The Ants. Belknap Press, Cambridge, MA, 732 pp.

Kilpeläinen J., Puntilla P., Sundström L., Niemelä P. \& Finér L. 2005: Forest stand structure, site type and distribution of ant mounds in boreal forests in Finland in the 1950s. Ann. Zool. Fenn. 42: 243-258.

Kilpeläinen J., Puntilla P., Finér L., Niemelä P., Domisch T., Jurgensen M.F., Neuvonen S., Ohasi M., Risch A.C. \& SundSTRÖM L. 2008: Distribution of ant species and mounds (Formica) in different-aged managed spruce stands in eastern Finland. J. Appl. Entomol. 132: 315-325.

LaAKSO J. \& SETÄLÄ H. 1997: Nest mounds of red wood ants (Formica aquilonia): hot spots for litter-dwelling earthworms. Oecologia 111: 565-569.

Lenoir L., Bengtsson J. \& Persson T. 2003: Effects of conifer resin on soil fauna in potential wood-ant nest materials at different moisture levels. Pedobiologia 47: 19-25.

Loones J., Maelfait J.-P., Van Rhijn J., Dekoninck W. \& ADRIAENS T. 2008: De rode bosmier in Vlaanderen: voorkomen, bedreigingen en herstelmaatregelen aan de hand van een detailstudie in de Sixtusbossen (Poperinge-Vleteren). Rapporten van het Instituut voor Natuur-en Bosonderzoek, 2008(1). [Red Wood Ants in Flanders: Distribution, Threats and Conservation Measures by Means of a Detailed Survey at the Sixtusbossen (Poperinge-Vleteren).] Instituut voor Natuuren Bosonderzoek, Brussel, 94 pp. [in Dutch, English abstr.].

$\therefore$ Instituut voor Natuur- en Bosonderzoek, Brussel, 94 pp (In Dutch, English abstract).

Mabelis A.A. 1979: Nest spliting by the red wood ant (Formica polyctena Foerster). Neth. J. Zool. 29: 109-125.

MABELIS A.A. 1984: Interference between wood ants and other ant species (Hymenoptera, Formicidae). Neth. J. Zool. 34: $1-20$.

Mabelis A.A. 1994: Flying as a survival strategy for wood ants in a fragmented landscape (Hymenoptera, Formicidae). Memor. Zool. 48: 147-170.

Mabelis A.A. 2002: Bruikbaarheid van mieren voor de monitoring van natuurgebieden. [Usefulness of Ants for Moni- toring Nature Reserves.] Alterra, Wageningen, 98 pp. [in Dutch].

Mabelis A.A. 2007: Do ants need protecting? Entomol. Ber. Amst. 67: 145-149.

Mabelis A.A. \& Chardon J.P. 2006: Survival of the trunk ant (Formica truncorum Fabricius) in a patchy habitat. Myrmecol. News 9: 1-11.

Mabelis A.A. \& KorczyńsKa J. 2001: Dispersal for survival: some observations on the trunk ant (Formica truncorum Fabricius). Neth. J. Zool. 51: 299-321.

MAEBE K. 2007: Genetische differentiatie bij rode bosmieren van het Formica rufa-complex. [Genetic Differentiation within Red Wood Ants of the Formica rufa-Complex.] Master thesis, Gent University [in Dutch].

Mäki-Petäys H., Zakharov A., Viljakainen L., Corander J. \& Pamilo P. 2005: Genetic changes associated to declining populations of Formica ants in fragmented forest landscape. Mol. Ecol. 14: 733-742.

Päivinen J., Ahlroth P. \& Kaitala V. 2002: Ant-associated beetles of Fennoscandia and Denmark. Entomol. Fenn. 13: 20-40.

Petal J. 1994: Reaction of ant communities to degradation of forest habitats in the Karkonosze Mountains. Memor. Zool. 48: $171-179$.

Piessens K., Honnay O., Nackaerts K. \& Hermy H. 2004: Plant species richness and composition of heathland relics in northwestern Belgium: evidence for a rescue effect? J. Biogeogr. 31: $1683-1692$

Piessens K., Honnay O. \& Hermy H. 2005: The role of fragment area and isolation in the conservation of heathland species. Biol. Conserv. 122: 61-69.

PisARSKI B. \& VePSÄLÄINEN K. 1989: Competition in ant communities (Hymenoptera, Formicidae). Ann. Zool. (Warsawa) 42: 321-328.

Puntilla P. 1996: Succession, forest fragmentation, and the distribution of wood ants. Oikos 75: 291-298.

Robinson N.A. 2001: Changes in the status of the Red Wood ant Formica rufa L. (Hymenoptera: Formicidae) in North West England during the 20th century. Br. J. Entomol. Nat. Hist. 14: $29-38$.

Rosengren R. \& Pamilo P. 1983: The evolution of polygyny and polydomy in mound-building Formica-ants. Acta Entomol. Fenn. 42: 65-77.

Rosengren R., Sundström L. \& Fortelius W. 1993: Monogyny and polygyny in Formica ants: the results of alternative dispersal tactics. In Keller L. (ed.): Queen Number and Sociality in Insects. Oxford University Press, Oxford, pp. 308-333.

Savolainen R., VepsäläINEN K. \& WuORENRINNE H. 1989: Ant assemblages in the taiga biome: testing the role of territorial wood ants. Oecologia 81: 481-486.

SEIFERT B. 1986: Vergleichende Untersuchungen zur Habitatwahl von Ameisen (Hymenoptera: Formicidae) im mittleren und südlichen teil der DDR. Abh. Ber. Naturkmus. Görlitz 59: $1-124$.

SeIfert B. 1991: The phenotypes of the Formica rufa complex in East Germany. Abh. Ber. Naturkmus. Görlitz 65: 1-27.

Seifert B. 2007: Die Ameisen Mittel- und Nordeuropas - lutra Verlags- und Vertriebgesellschaft. Klitten, 368 pp.

SkinNer G.J. 1980: The feeding habits of the wood ant Formica rufa (Hymenoptera: Formicidae), in limestone woodland in North-West England. J. Anim. Ecol. 49: 417-433.

SORVARI J. \& HAKKARAINEN H. 2005: Deforestation reduces nest mound size and decreases the production of sexual offspring in the wood ant Formica aquilonia. Ann. Zool. Fenn. 42: 259-267. 
Vepsäläinen K., Savolainen R., Tiainen J. \& Vilén J. 2000 Successional changes of ant assemblages: from virgin and ditched bogs to forests. Ann. Zool. Fenn. 37: 135-149.

Wils C., Paelinckx D., Adams Y., Berten B., Bosch H., De Knijf G., De Saeger S., Demolder H., Guelinckx R., Lust P., Oosterlynck P., Scheldeman K., T’Jollyn F., Van Hove M.,
VAndenbussche V. \& VRIEns L. 2004: Biologische Waarderingskaart en natuurgerichte bodembedekkingkaart van het Vlaamse Gewest. [Biological Validation Map and Ground Cover Maps of the Flemish District.] Instituut voor Natuurbehoud IN. R2004.08, Brussel, 39 pp. [in Dutch].

Received April 4, 2009; revised and accepted December 18, 2009 